保健物理, 21, 251 256 (1986)

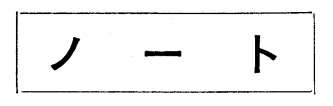

\title{
実効線量当量と性別・年齢別リスク荷重線量当量の 関連に関する考察
}

\author{
占 部 逸 正*1 $^{* 1}$
}

\author{
(1985 年 12 月 5 日受理) \\ (1986 年 5 月 17 日再受理)
}

\begin{abstract}
Study on a Relation between Effective Dose Equivalents and Risk Weighted
Dose Equivalents Depending on Age and Sex
\end{abstract}

Itsumasa URABE*1

KEY WORDS : effective dose equivalent, organ or tissue dose, dose equivalent limits, stochastic risk, weighting factor, photon energy spectrum

\section{I 序}

放射線被曝によるリスクの表現体としての実効線量当 量は，線質の異なる放射線による被曝をひとつの線量概 念で評価できるとともに全身被曝と局所被曝を統一して 把握できる量であり放射線防護上きわめて有効な概念で ある1)。しかし同時に実効線量当量を求める際の確率的 影響に関するリスクの荷重係数には, 各個人について差 異のあることを認めながらも, すべての年齢, 両性に同 一の值を採用しているため, 特定の個人のリスクを表現 する量としてとらえると大きなあいまいさを伴ったもの とならざるをえない。

放射線作業従事者個々の生涯を通じた被曝の状況はき わめて多様で, これらをすべて考慮することは一般に不 可能である。しかし実効線量当量がリスクの表現体とし て導入された量であることを考慮すると，個人について もでさるだけ実際のリスクを考慮した被曝管理の方法を 採用することにより，(1)個人の状沉を反映した安全性の 高い作業計画の立案が可能となることや，(2)放射線作業 に従事した期間のリスクの積算が可能となることなど安

*1 京都大学原子炉実験所放射線管理研究部門; 大阪府泉南 郡熊取町野田（干590-04）

Division of Radiation Protection, Research Reactor Institute, Kyoto University, Kumatoricho, Sennan-gun, Osaka-fu 590-04.
全管理の信頼性や合理性を飛躍的に向上させることがで きる。

実効線量当量と被曝した個人のリスク間のあいまい性 から生じる危険を最小限にするための実務的な方法とし て，認定限度などの防護基準を十分低く括さえることも 考兄らるが，とくに変化の著しい性別・年齢別のリス ク荷重線量当量を評価し，これを安全管理の実務に反映 することも最適化の観点から重要である。またこの方法 は, あるひとつの被曝集団に対し, 性別・年齡別に与え られたリスク荷重線量当量に基づく集団線量当量の評価 を可能にすることからも検討に值するものと考えられ る。

最近 D. BENINSON と D. SowBY2) は医療上の被曝 を実効線量当量と比較するために ICRP 報告3)に基づい て確率的影響の性別・年齢別リスク係数を提案している。 このリスク係数を使用した線量当量は, 多くの不確定さ を有しつつも性別 ·年龄別に分類した個人的状況をいく らかでも勘案した量を与えることができる。ここでは放 射線被懪による確率的影響の個々人のリスクを評価する ひとつの試みとして性別・年齢別リスク荷重線量当量を 定義し, 照射線量に対する換算係数 (以後, 性別・年齢 別リスク荷重線量当量換算係数と呼ぶ）を照射条件を考 慮し決定した。さらに実際のガンマ線場で作業者の年齿 ・性によるリスク荷重線量当量の変化の特徵を調べ，放 射線作業従事者の年跉別構成 ${ }^{4)}$ に基ついて得られるリス 
ク荷重線量当量の平均值と ICRP の勧告したリスクの荷 重係数 ${ }^{1}$ に基ついて得られる実効線量当量との関連を検 討した。

\section{II 性別・年齢別リスク荷重線量当量の評価法}

実効線量当量 $\left(H_{\mathrm{E}}\right)$ はよく知られているように各種臓 器・組織の線量当量 $H_{\mathrm{T}}$ に確率的影響のリスクの全体の リスクに対する割合をしめす荷重係数 $w_{\mathrm{T}}$ を乗じて得ら れる。

$$
H_{\mathrm{E}}=\sum_{\mathrm{T}} w_{\mathrm{T}} \cdot H_{\mathrm{T}}=\sum_{\mathrm{T}} w_{\mathrm{T}} \cdot D_{\mathrm{T}} \cdot Q \cdot N
$$

ここで $D_{\mathrm{T}}$ は臓器 $\mathrm{T}$ の吸収線量, $Q$ は線質係数, $N$ は照 射条件などの修飾因子で ICRP は現在これを1としてい る。

性別・年㱓別に分けた場合の i グループに属する個人 のリスク荷重線量当量 $\left(\mathrm{WDE}_{i}\right)$ は, 荷重係数の取扱い が異なるだけで実効線量当量と同様の考え方に従って得 ることができる。

$$
\mathrm{WDE}_{i}=\sum_{\mathrm{T}} p_{i \mathrm{~T}} \cdot H_{i \mathrm{~T}}=\sum_{\mathrm{T}} p_{i \mathrm{~T}} \cdot D_{i \mathrm{~T}} \cdot Q \cdot N
$$

ここで $p_{i \mathrm{~T}}$ は D. BENISON と D. SowBY の示した ponderation factors で各年略の臓器別リスク係数を ICRP の与えた放射線防護のための全身均等被曝のリス ク係数で除した量である。ガンマ線による外部被曝の場 合， $D_{i \mathrm{~T}}$ はしばしばグループ $i$ にいてとれほど大きく 異ならないことを仮定し，あるエネルギー領域 $j$ のガン マ線による単位照射線量に対する臓器吸収線量換算係数 $d_{i \mathrm{~T} j}$ (以後, 蔵器吸収線量換算係数と呼ぶ）を用いて決 定される。またこの場合 $Q=1$ となるためリスク荷重線 量当量は照射線量 $E_{j}$ と

$$
\mathrm{WDE}_{i}=\sum_{j} \sum_{\mathrm{T}} p_{i \mathrm{~T}} \cdot d_{i \mathrm{~T} j} \cdot E_{j}=\sum_{j} f_{i j} \cdot E_{j}
$$

の関係で示される。ここで $f_{i j}$ はエネルギー領域 $j$ のガ ンマ線に対する性別・年齢別リスク荷重線量当量換算係 数である。

体外のガンマ線に対する臓器吸収線量の研究は数多く 行われ5 12), 日本人を対象としたものもいくつか報告さ れている ${ }^{5,6)}$ 。神永らはとくに生殖腺に対する吸収線量を 与元, 丸山らは実効線量当量の評価を意図して多くの蔵 器を対象として吸収線量の評価を行っている。ここでは 和もに後者の結果に基づいて臓器吸収線量換算係数を決 定した6)。丸山らは放射線作業従事者のフィルムバッジ の読取り值から実効線量当量を推定するために, $0 \sim 1.25$ $\mathrm{MeV}$ のエネルギー領域で換算係数を得ているが，ここ では原子炉施設周辺で〜10 MeV のエネルギー領域の換 算係数を必要とするため丸山らの結果を KRAMER と
DREXLER ${ }^{7)}$ やJONES ら ${ }^{11)}$ の結果を参考に $10 \mathrm{MeV}$ ま で外挿した。また前方照射条件で，しかも 方向からの入射を考慮した場合の臓器吸収線量換算係数 は文献6)に与兄られた結果から同じ文献に示されたフィ ルムバッジの感度補正をしてこれを決定した。性別・年 齢別リスク荷重線量当量換算係数を決定するために考慮 した臓器は, 生殖腺, 乳房, 骨髄, 肺, 甲状腺, 骨表面 およびその他の蔵器で, 骨表面は低エネルギー光子にた いする応答に問題が残るが赤色骨髄で代用した。またそ の他の臓器としては, 胃, 小腸, 大腸, 肝臓, すい臓を 選んだ。

得られた性別・年齢別リスク荷重線量当量換算係数を 実際の放射線作業環境での線量当量の評価に応用し，そ の年齢による変化の特徵を調べるための一例として, 京 大原子炉実験所に設置された研究炉が $5 \mathrm{MW}$ で運転さ れているときの比較的広いエネルギ一範囲を有する原子 炉室内ガンマ線エネルギー分布を使用した。ガンマ線エ ネルギー分布の測定には, 直径 $7.6 \mathrm{~cm}$, 長さ $7.6 \mathrm{~cm}$ の結晶を有する $\mathrm{NaI}(\mathrm{Tl})$ 検出器を使用し, 得られた波高 分布から真のガンマ線エネルギ一分布を評価するための 応答関数は文献 13）の $0 \sim 9.2 \mathrm{MeV}$ のエネルギー領域 のものを使用した。

\section{III 結果および考察}

照射線量対リスク荷重線量当量換算係数を性別・照射 条件別に Fig. 1 4 に示す。図の縦軸は臟器の線量当量 に ponderation factors を乗じて得られる性別・年齢別 リスク荷重線量当量を照射線量で除したリスク荷重線量 当量換算係数を示す。眓中のパラメータは，年齢を表わ

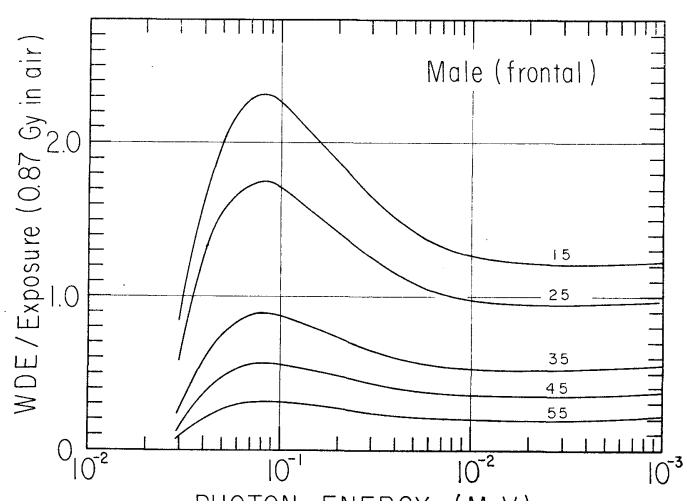

PHOTON ENERGY (MeV)

Fig. 1 Risk weighted dose equivalent, WDE (Sv) per unit exposure in free air $(0.87 \mathrm{~Gy}$ in air), frontal whole body irradiation. Numbers show the age. 


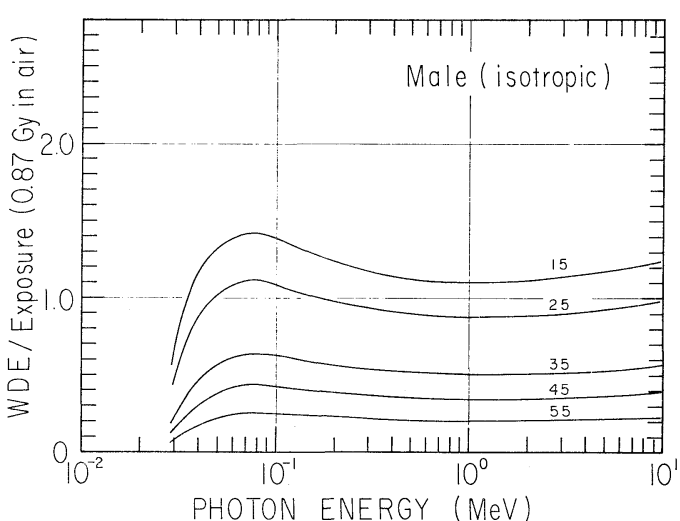

Fig. 2 Risk weighted dose equivalent, WDE (Sv) per unit exposure in free air $(0.87 \mathrm{~Gy}$ in air), isotropical whole body irradiation. Numbers show the age.

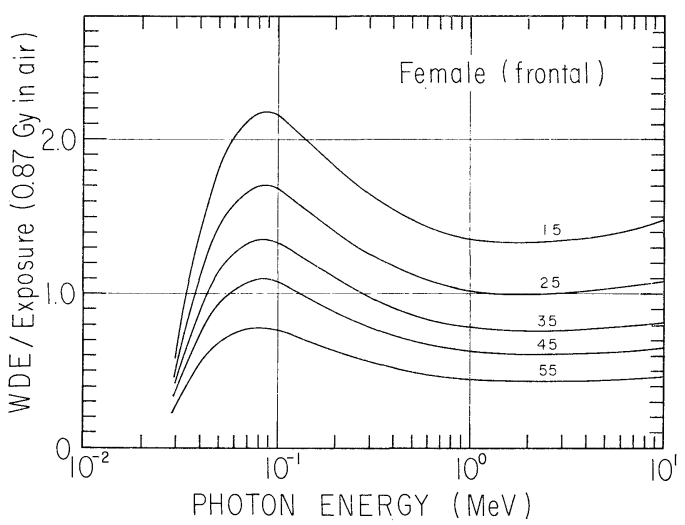

Fig. 3 Risk weighted dose equivalent, WDE $(\mathrm{Sv})$ per unit exposure in free air $(0.87 \mathrm{~Gy}$ in air), frontal whole body irradiation. Numbers show the age.

し，上から順に 15，25，35，45 和よび 55 歳の結果を 示す。それ以上はさらに小さくなるので省略した。図の リスク荷重線量当量換算 係数の精度は, ponderation factors を固定して考光ると各臟器の吸収線量換算係数 の精度に依存し, $1 \mathrm{MeV}$ 以下のエネルギー領域で \pm 20 $\%, 1 \mathrm{MeV}$ 以上の高エネルギー側で $\pm 10 \%$ 程度の誤差 を含むものと考学られる。とくに前者では照射条件によ って換算係数が大きく異なり単一の係数を使用すること 自体大きい誤差を伴うものと思われる。

Fig. 1，3 亿示した前方照射条件に和けるリスク荷重 線量当量換算係数では，いずれの場合にも年龄が若いほ どより大きなエネルギー依存性を示す。これらは，男性 の場合生殖腺に対する荷重係数の寄与が大きいことに，

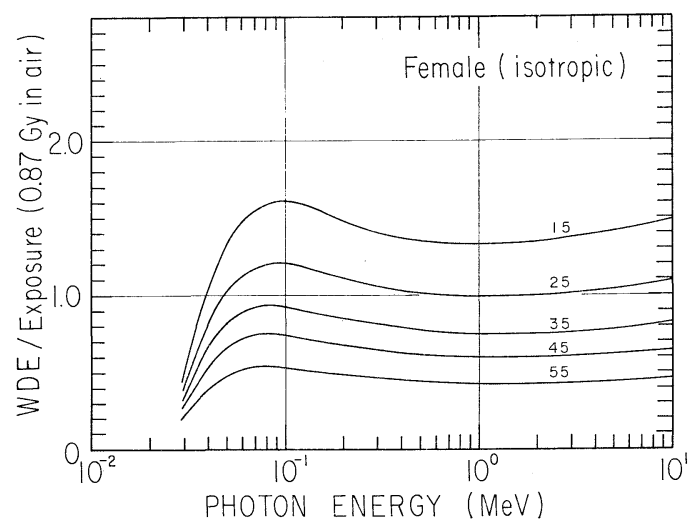

Fig. 4 Risk weighted dose equivalent, WDE (Sv) per unit exposure in free air $(0.87 \mathrm{~Gy}$ in air), isotropical whole body irradiation. Numbers show the age.

女性の場合扣もに乳房に対する荷重係数の奇与が大きい ことに起因している。また若い女性の場合，光子のエネ ルギーが高くなるにしたがい換算係数が大きくなる傾向 が著しいが，これは拉もに生殖腺注対する遮蔽効果が減 少したことによるるのと考光られる。

Fig. 2，4 亿示す均等照射条件でのリスク荷重線量当 量換算俰数では，女性の場合乳房の寄与が著しく，男性 にくらべ全般にリスク荷重線量当量換算係数が大きくな る傾向にある。換算俰数を性別でくらべると最大值の現 れるエネルギー位置が少し異なり女性の活らが高くなる 傾向にある。李た数 $\mathrm{MeV}$ の高エネルギー側では照射条 件の違いによる差異が小さくなることも明らかである。 以上のように換算係数のエネルギー依存性は, 各臟器·組 織のリスク係数の大きさとともに臟器・組織の生体内で の位置に強く依存して得られる。文献3)にも述べている ようにここで使用した ponderation factors は, 多くの 不確定さを残しているが，今後りスク係数の研究が進む につれこれらの信頼性の向上が期待できるるのと思われ る。

Fig. 5 亿京大原子炬実験所の KUR 炉室内の重水照 射設備前で得たガンマ線エネルギ一分布を示す。図に示 すように炉室内では減速材や構造材との中性子捕獲反応 や放射化によるガンマ線あるいは空気の放射化によるガ ンマ線, 抢よびこれらによる散乱線が観測されるのが一 般的である。ガンマ線エネルギー分布に基づく空気の吸 収エネルギー率は $0.51 \mu \mathrm{Gy} / \mathrm{hr}(58.4 \mu \mathrm{R} / \mathrm{hr})$ である。 各年龄のリスク荷重線量当量換算係数を使用してガンマ 線エネルギー分布から計算したリスク荷重線 量 当量を Fig. 6 飞示す。各年齢に対するなめらかな曲線を仮定 


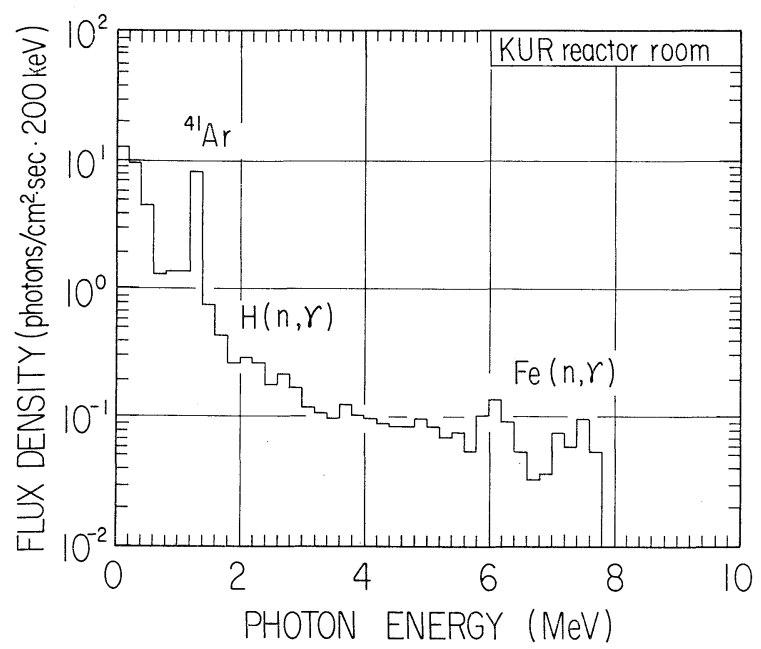

Fig. 5 Gamma-ray energy spectrum obtained around the heavy water irradiation facility in the KUR reactor room.

して結えだ。図中の実線物よび破線は男性の場合の前方 照射と均等照射にそれぞれ対応し，一点鎖線および二点 鎖線は女性の場合の前方照射と均等照射にそれぞれ対応 する。また白丸拉よび四角は ICRP の勧告する荷重保数 を使用した場合の実效線量当量を示す。ここで男性の 場合は乳房の荷重係数を 0 としている。図の結果から 30 33 歳前後を境として若年層でリスク荷重線量当量 が実効線量当量を上回っていることまたりスク荷重線 量当量の年齢依存性は, ponderation factors の大きさ に応じた各臟器・組織の線量当量が考慮されているにも かかわらず，ICRP の与えるリスク係数の年齢依存性 ${ }^{3)}$ と汪济同様の傾向を示していることなどがわかる。しか 乙同時に図からガンマ線エネルギー分布に極端な偏りが ある場合には，これらは多少異なった傾向を示すことも 予想される。照射条件別では, 女性の場合あまり顕著な 差異が認められないのに対し，30歳以下の男性の場合照 射条件の違いによる変動幅が広くなりここで設定した照 射条件下では，15\% 程度の差が現れている。

リスク荷重線量当量の年路依存性のひとつの応用例と して性別・年齢別リスク荷重線量当量の平均値と実效線 量当量の比較を試みた。京大原子炬実験所では年間 300 名を超える研究者による共同利用研究が行われている。 しかしその作業内容は複雑で作業環境のガンマ線エネル ギー分布も多椂である。また研究者の年齢分布も現在の ところ明かにされていない。したがって放射線場の典型 例として Fig. 5 の結果を, また研究者の年齢構成比を わが国の研究・教育に従事する放射線作業者の年齢分 布 ${ }^{4)}$ と同一のものと仮定して年㱓別リスク荷重線量当量

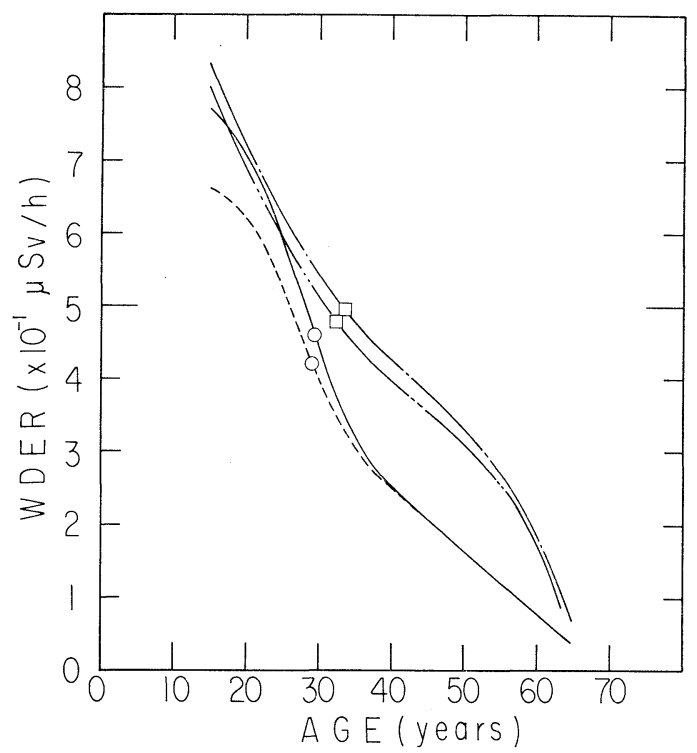

Fig. 6 Variation of risk weighted dose equivalent rates (WDER) as a function of age of a worker. Solid and broken lines show the frontal and isotropical irradiation for male, respectively, and upper and lower chain lines show the frontal and isotropical irradiation for female, respectively. $O$ and $\square$ represent the effective dose equivalent rates for male and female, respectively.

の平均値を計算した。Table 1 の第 5 欄に年齢別リスク 荷重線量当量の平均値を示す。表の第 3 欄には照射線量 を，第 4 欄には ICRP の勧告值を使用した場合の実效線 
Table 1 Comparison among exposure rates, effective dose equivalent rates and risk weighted dose equivalent rates.

\begin{tabular}{ccccc}
\hline Sex & Condition* & ER $(\mu \mathrm{R} / \mathrm{hr})$ & EDER $(\mu \mathrm{Sv} / \mathrm{hr})$ & WDER $(\mu \mathrm{Sv} / \mathrm{hr})$ \\
\hline \multirow{2}{*}{ Male } & iso. & & 0.42 & 0.37 \\
& & 58.4 & & 0.40 \\
\multirow{2}{*}{ Female } & fro. & & 0.46 & 0.53 \\
& iso. & 58.4 & 0.48 & \\
& fro. & & 0.50 & 0.56 \\
\hline
\end{tabular}

* iso. and fro. mean isotropic and frontal irradiation conditions.

ER : Exposure rate.

EDER : Effective dose equivalent rate.

WDER : Risk weighted dose equivalent rate averaged over the age distribution of radiation workers.

量当量を比較のために示した。表から男性の場合，実効 線量当量がリスク荷重線量当量の平均值より高いのに対 し，女性の場合は低くなる傾向にあることがわかる。こ れらの違いはいずれの場合も実効線量当量の $10 \%$ 程度 となって抢り，放射線作業従事者の分布の偏りや臟器 • 組織のリスクの荷重係数, とくに乳房の荷重係数の取扱 いの差異に起因したものと思われる。

以上のように単一の作業環境を仮定した場合のリスク 荷重線量当量の平均値と実効線量当量の相違は, $10 \%$ 程 度と比較的近い値となっているが, リスク荷重線量当量 と実効線量当量の関連を詳しく知るためにはさらに広範 な作業環境に和けるガンマ線エネルギー分布情報や放射 線作業者の年龄分布情報に基づいた検討が必要である。

\section{IV 結 論}

以上の検討の結果つぎの結論が得られた。

1） $0 \sim 10 \mathrm{MeV}$ のエネルギー領域の ガンマ線に 対す る照射線量対性別・年齢別りスク荷重線量当量換算係数 を決定し，原子炬施設周辺環境等でのガンマ線エネルギ 一分布情報に基づくリスク荷重線量当量の評価を可能と した。

2）全身照射の場合に和ける性別・年齢別リスク荷重 線量当量は，原子炉周辺の広いエネルギー範囲を有する ガンマ線場で ICRP の示すリスク係数の年龄依存性と注 ぼ同様の傾向を示すが，照射条件に極端な片寄りがある 場合, とくに 30 歳以下の男性の場合 10 数\%程度のば らつきが認められる。

3）研究 - 教育に従事する放射線作業従事者の性別 · 年龄別構成任基づくリスク荷重線量当量の平均値と実効 線量当量を比較すると，両者の差異は約 $10 \%$ と比較的 小さいが，実際の放射線作業環境の特徵や放射線作業従
事者の年齢分布に基づく詳しい検討が必要である。

\section{参 考 文 献}

1) ICRP ; Recommendations of the international commission on radiological protection, ICRP Publication 26 (1977), Pergamon Press, Oxford.

2) D. Beninson and D. Sowby; Age and sex dependent weighting factors for medical irradiation, Radiat. Prot. Dosim., 11, 57 (1985).

3) ICRP ; Problems of developing and index of harm, ICRP Publication 27 (1977), Pergamon Press, Oxford.

4）千代田保安用品株式会社；58年度年齢・性別被ば く線量の実態, フィルムバッジニュース，118号， 11 (1985).

5）神永博史, 熊沢 蕃, 古田敏城, 立田初巳; 外部 被暴による単位照射線量あたりの臟器吸収線量の 比較検討, 保健物理, 10, 193 (1975).

6) T. Maruyama, K. Nishizawa, Y. Noda, E. TAKEDA, K. FukUHisa, Y. FuruYa and T. HASHIzUME ; Estimation of population doses and risk estimates from occupational exposure in Japan, 1978 Part 1, Determinations of organ or tissue doses and effective dose equivalents, J. Radiat. Res., 22, 182 (1981).

7) R. Kramer and G. Drexler ; on the calculation of the effective dose equivalent, Radiat. Prot. Dosim., 3, 13 (1982).

8) M. Rosenstein ; Dose equivalent conversion factors for human organs and tissues from 
external radiation, Int. J. Appl. Radiat. Isot., 23, 1051 (1982).

9) G.D. KERR; A review of organ doses from isotropic fields of $\gamma$-rays, Health Phys., 39, 3 (1980).

10) K. O'BRIEn and R. SANNA; The distribution of absorbed dose-rates in humans from exposure to environmental gamma rays, Health Phys., 30, 71 (1976).

11) T.D. Jones, J.A. Auxier, W.S. SNyder and
G.G. WARNER; Dose to standard reference man from external sources of monoenergetic photons, Health Phys., 24, 241 (1973).

12) J.R. Jones; Proposed calibration factors for various dosimeters at different energies, Health Phys., 12, 663 (1966).

13) Y. NAKASHIMA; Study on evaluation of photon spectra and exposure rates in the radiation fields around nuclear reactors, Doctor's Thesis, Nagoya Univ. (1979). 